\title{
Temporal Variation of the Stratospheric Aerosol Layer after the Fuego Eruption observed by Lidar in Fukuoka
}

\author{
By Toshikazu Itabe*, Motowo Fujiwara and Motokazu Hirono \\ Department of Physics, Kyushu University, Fukuoka 812 Japan \\ (Manuscript received 21 April 1977, in revised form 13 September 1977)
}

\begin{abstract}
The eruption of the Fuego in Guatemala injected a large amount of volcanic substances to the lower stratosphere in mid-Oct. '74. About a month later, an extraordinary intense scattering layer was observed by ruby lidar in the lower stratosphere over Fukuoka. The peak value of the non-molecular radar cross section showed a maximum in Dec. '74. It decreased gradually after spring ' 75 and attained a secondary maximum in early autumn of the year. The height of the layer peak was located a few kilometers below the normal Junge layer and the half width of the layer which was initially a few kilometers increased as the peak value of the non-molecular radar cross section decreased.

The gross feature of the temporal variation of the peak value observed by lidar is in contradiction to the results expected from the 2-dimensional transport models proposed up to this time and the contradiction can not be explained if we consider only the case where the observed radar cross section is assumed to be a good conservative quantity. It is suggested that some kinds of in situ formation process should occur in the lower stratosphere.
\end{abstract}

\section{Introduction}

Following the eruption of the Fuego $\left(14.5^{\circ} \mathrm{N}\right.$, $90.0^{\circ} \mathrm{W}$ ), a large increase of the stratospheric aerosols was observed in the world by various methods i.e. measurements with twilight color (Volz, 1975), lidar (Fegley and Ellis, 1975), in situ optical particle counter (Hofmann and Rosen, 1975), impactor (Ferry and Lem, 1975), and so on. Lidar observations of the stratospheric aerosols in Fukuoka had begun in Oct. 72 and revealed the appearance of an extraordinary intense scattering layer in mid-Nov. '74 associated with the Fuego eruption. The peak values of non-molecular radar cross section $\beta_{M}$ which stands for $4 \pi$ times differential backscattering coefficient at the lidar wavelength reached some ten times those of the pre-volcanic layer and varied in a rather complex manner from mid-Nov. '74 to Feb. '75. After spring '75 it decreased gradually and had a secondary maximum in early autumn of the year. The provisional results of lidar observations from Oct. '74 to Feb. '75 were reported in a previous paper (Fujiwara et al., 1975).

In this paper, results of the lidar observations

* Present affiliation: Radio Research Laboratories. after Mar. '75 are presented and are compared with those obtained from 2-dimensional models proposed by Gudiksen et al. (1968) and Cadle et al. (1976). We discuss only the case where the observed value $\beta_{M}$ is assumed to be a good conservative property. The results from the 2dimensional models mentioned above can not explain the temporal variations of $\beta_{M}$ observed both in Fukuoka and Menlo Park (S. R. I.) consistently, in this case. If we adopt the Gudiksen's model, another case has to be considered, where in situ particle formation process in the lower stratosphere is taken into account. This case will be discussed in more detail in a later paper (Hirono et al., to be published).

\section{Method of observation and analysis}

The instrumentation of our lidar was described in the previous paper in detail including the results of the early stage observation (Hirono et al., 1974). The equipment consists of a ruby laser which produces 1 to 1.5 joule giant pulse for the optimum input energy, a $10 \mathrm{~cm} \phi$ transmitting telescope and a $30 \mathrm{~cm} \phi$ receiving telescope. For every night observation the number of total firing is about 300 shots with the repetition of 6 pulses per min. The return photon 
signals from the atmospheric constituents are converted to electronic pulses by a photomultiplier. The pulses are counted in each 0.75 $\mathrm{km}$ height interval and the counts are accumulated for the total shots of a night. Then the height profiles of the photon counts are drawn for a height range between 12 and $17 \mathrm{~km}$ for the period from Mar. '75 to Jan. '76 and between 9 and $30 \mathrm{~km}$ after Feb. '76.

The profile of photon count $C(h)$ is given by

$$
C(h)=K \frac{\beta_{R}(h)+\beta_{M}(h)}{h^{2}}
$$

where $K$ is a constant for the particular lidar including a transmission coefficient of the atmosphere and a height interval $\Delta h, \beta_{R}(h)$ and $\beta_{M}(h)$ are molecular and non-molecular radar cross sections, respectively. The non-molecular radar cross section $\beta_{M}(h)$ can be determined using the observed values of $C(h)$, if informations on the parameters $\beta_{R}(h)$ and $K$ are given. The molecular radar cross section $\beta_{R}(h)$ is calculated by a molecular density profile (U.S. Standard Atmosphere 1962) neglecting its temporal variations at the present stage. It is, however, very troublesome and difficult to determine the value of $K$ only by the usual one color lidar. In the present, therefore, we adopt the matching method i.e. we assume that the atmosphere at a certain height $h_{o}$ within the height region spanned by lidar involves negligible aerosol content. At the height $h_{o}$, eq. (1) is given as follows,

$$
C\left(h_{0}\right)=K \frac{\beta_{R}\left(h_{0}\right)}{h_{0}^{2}}
$$

and from eqs. (1) and (2), $\beta_{M}(h)$ is given by

$$
\beta_{M}(h)=\left\{\frac{C(h)}{C\left(h_{0}\right)} \cdot{ }_{h_{0}^{2}}^{h^{2}} \cdot \frac{\beta_{R}\left(h_{0}\right)}{\beta_{R}(h)}-1\right\} \beta_{R}(h)
$$

In the analysis of lidar data by the matching method, it is very important how to choose the height of normalization $h_{o}$. We choose the height $h_{o}$ according to the following rule: when the resulting non-molecular radar cross section $\beta_{M}(h)$ for an arbitrary $h_{o}$ is positive or zero within the limits of the probable error of the photon counting over the observed height region, then the height $h_{o}$ is chosen to be the height of normalization. The height $h_{o}$ is located typically below nearly $15 \mathrm{~km}$ or above nearly $25 \mathrm{~km}$. At present, the photon counts from the upper region are so few that the photon counting error is fairly large. This error gives bad influence on the accuracy of $\beta_{M}(h)$ at all heights as can be seen readily in eq. (3), if we choose the height of normalization to be around $25 \mathrm{~km}$. So we adopted the data which resulted from the choice of the height $h_{o}$ below $15 \mathrm{~km}$ and omitted the other ones of which the height $h_{o}$ was located around or above $25 \mathrm{~km}$. It is necessary to know the matching method can lead to underestimate the stratospheric aerosol content in any case.

The scattering ratio $R(h)$ which is usually used in the discussion of lidar observations is given as follows,

$$
R(h)=1+\frac{\beta_{M}(h)}{\beta_{R}(h)}
$$

In this paper, however, we use the radar cross section $\beta_{M}(h)$.

\section{Observational results and comparison with 2-dimensional models}

Examples of the vertical profiles of $\beta_{M}$ and $R$ analyzed by the matching method mentioned in the previous section are shown in Fig. 1. According to the local rawinsonde soundings carried out by the Fukuoka Meteorological Observatory the mean height of a tropopause which extends from the equatorial region is about $16 \mathrm{~km}$ in all seasons and in winter another tropopause appears at height lower than the former. The peak height of the post Fuego stratospheric aerosol layer is about $2 \mathrm{~km}$ higher than the upper tropopause, as shown in Fig. 1. Taking account of the lidar observations in the other stations, i.e., Hawaii, Virginia and California, the volcanic substances injected by the Fuego would have been transported horizontally along the height of the tropopause extended from equator in the lower latitude region. The thickness of this layer was about $3 \mathrm{~km}$ in the first stage after the Fuego eruption and became broader gradually. Then secondary small peak began to appear occasionally above $20 \mathrm{~km}$ after spring '75.

Peak values of $\beta_{M}$ observed in Fukuoka are plotted in Fig. 2 for the period from Oct. '74 through Sep. '76. The results of Stanford Research Institute observed in Menlo Park, California (Russel et al., 1976) are also plotted in the figure. The provisional results during five months after the Fuego eruption were published previously (Fujiwara et al., 1975). The peak values decrease up to Aug. ' 75 and then have a secondary maximum in early autumn, as shown in Fig. 2. According to Dyer and Hicks (1968), it is indicated by the analysis of the decrement of the direct solar radiation that the winter maxima of 


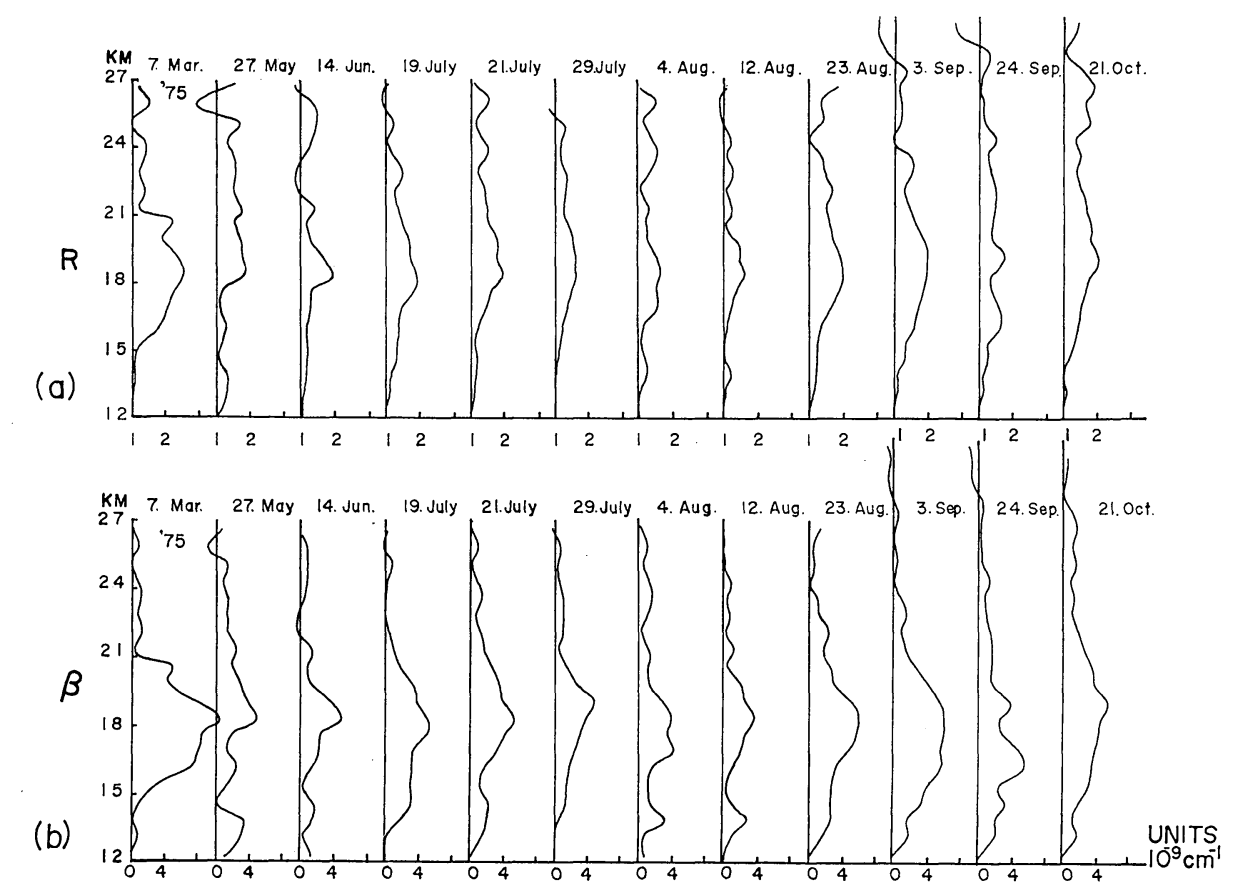

Fig. 1 Examples of height profiles of (a) scattering ratio $R(h)$ and (b) non-molecular radar cross section $\beta_{M}(h)$.

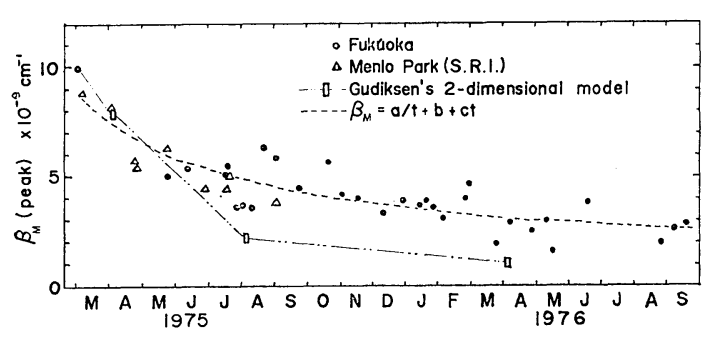

Fig. 2 Temporal variation of peak values of radar cross section $\beta_{M}$ (peak), their approximated curve and mixing ratios of $W^{185}$ calculated according to Gudiksen et al. For the approximated curve, the constants, $\mathrm{a}, \mathrm{b}$ and $\mathrm{c}$, are $1.07 \times 10^{3} \mathrm{sec} \mathrm{cm}^{-1}, 1.32 \mathrm{~cm}^{-1}$ and $3.93 \times 10^{-4} \mathrm{sec}^{-1} \mathrm{~cm}^{-1}$ respectively.

the volcanic dust progressed polewards within a few years following the Agung eruption in 1963. In the case of post Fuego, however, other stations which have been observing the stratospheric aerosol layer have not reported the secondary maximum. The secondary maximum in early autumn observed in Fukuoka may, therefore, be rather local phenomenon. In this paper, we consider only a gross feature of temporal variation of the peak values and compare it with the 2dimensional models proposed by Gudiksen et al.
(1968) and Cadle et al. (1976).

In order to consider the gross temporal variation of the peak values of $\beta_{M}$, we draw a curve of approximation in Fig. 2. The curve is in the form of a function which involves an asymptotic solution of a diffusion equation in the first term as follows,

$$
\beta_{M}(\text { peak })=\frac{a}{t}+b+c t
$$

where $t$ is time in unit of day reckoned from the Fuego eruption, a, b, and c are constants which are determined by the least square method. The approximated function fits fairly well the observed values of $\beta_{M}$, as shown in Fig. 2. Assuming that the stratospheric aerosols and gases injected by the Fuego eruption have been homogeneous along the latitudinal circle since Mar. '75, we compare the approximated curve with the calculated values of 2-dimensional models.

When we compare the temporal variation of the stratospheric aerosols by lidar with the 2dimensional models, it is necessary to examine whether or not the observed value of $\beta_{M}$ is a conservative quantity. The radar cross section $\beta_{M}$ is written as follows,

$$
\beta_{M}(h, t)=4 \pi \int \sigma(r, m, \lambda) n(r, h, t) d r
$$


where $\sigma$ is backscattering cross section of an aerosol particle with radius $r, m$ the refractive index for a wavelength $\lambda$, and $n(r, h, t)$ the number density of aerosols with radii between $r$ and $r+d r$. As shown in eq. (6), the observed value $\beta_{M}$ depends on the two parameters, refractive index $m$ and size distribution $n(r, t)$. The former depends on the composition and phase of the aerosol particles. The recent in situ measurement indicated that the aerosol particles injected by the Fuego eruption were sulfuric acid droplets after Mar. '75 (Ferry and Lem, 1976; Hofmann and Rosen, 1975). We adopt the refractive index of the post Fuego aerosols to be 1.41 which is the same one as the pre Fuego aerosols composed of a $75 \%$ solution of sulfuric acid (Toon and Pollack, 1973). Then $\sigma$ can be computed for an aerosol particle with any radius by Mie theory.

The size distribution of the aerosol particles is controlled by many complex processes, coagulation, nucleation, sedimentation and so on. In the present, it is impossible to solve a time dependent equation involving all processes and to describe the evolution of the size distribution. So we confine our attention only to the coagulation process. More detailed discussion including other processes, especially, nucleation, will be described in a later paper. The equation including only a coagulation process is the simplest one, which can be solved numerically. The results of calculation shows that the size distribution within the optically effective size range between nearly 0.1 and $1.0 \mu \mathrm{m}$ in the lower stratosphere does not change significantly if the initial distribution is assumed to be Haze $\mathrm{H}$ proposed by Deirmendjian (1969; see also Russel et al., 1974) and power law proposed by Friedlander (1960; see also Hirono et al., 1974), and that the evolution of the size distribution has little effect on the temporal variation of the observed values of $\beta_{M}$. In this case where the size distribution depends only on the coagulation, the observed value $\beta_{M}$ is a good conservative quantity and the function of eq. (5) should be fitted fairly well to the calculated ones by the 2-dimensional transport model.

One of the 2-dimensional models was proposed by Gudiksen et al. (1968) in order to explain the global spread of $\mathrm{W}^{185}$ injected into the lower stratosphere by nuclear weapon test. (the Hardtack test, 1958). For the numerical calculation the trace substance $\mathrm{W}^{185}$ was assumed to have sources at $11^{\circ} \mathrm{N}$ in the heights of 18 and $19.5 \mathrm{~km}$ on June 15, '58. The latitude of the volcanic injection is $14.5^{\circ} \mathrm{N}$ which is not so far from $11^{\circ} \mathrm{N}$ and interval of latitude between $11^{\circ} \mathrm{N}$ and $30^{\circ} \mathrm{N}$ is equivalent to that between $14.5^{\circ} \mathrm{N}$ and $33.5^{\circ} \mathrm{N}$. Because the principal mechanism of the transport in their model is the horizontal eddy diffusion of which the coefficients are nearly constant in any seasons, the initial time of their model can be shifted to the date of the volcanic eruption (Oct. 16, '74). Peaks of the vertical mixing ratio profiles of $W^{185}$ calculated by their model are located near the height of $18 \mathrm{~km}$ at $30^{\circ} \mathrm{N}$ during 18 months. The variation of peak mixing ratio is shown by rectangles in Fig. 2, where it is indicated that the overall decay of the approximated curve mentioned above is much slower than the calculated one. The 2-dimensional model proposed by Gudiksen et al. can not, therefore, explain the results of lidar observations.

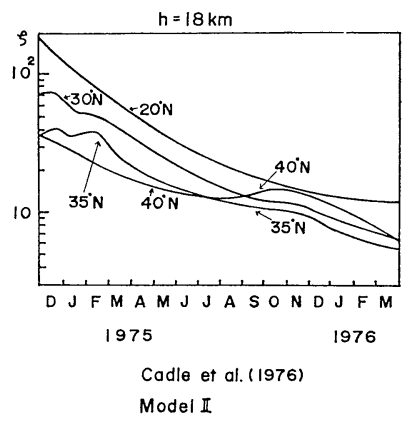

Fig. 3 Relative concentrations of the trace substance at altitude $18 \mathrm{~km}$ on different latitudes according to the 2-dimensional model proposed by Cadle et al.

Another 2-dimensional model was proposed by Cadle et al. (1976; see also Louis, 1974) and is able to explain our approximated curve better. Fig. 3 shows the relative concentrations of the trace substance at different latitudes according to the model of Cadle et al. The decay feature of this model has, however, large variability against the latitude near $30-40^{\circ} \mathrm{N}$, in contradiction to the results observed at two different stations, Fukuoka $\left(33^{\circ} \mathrm{N}\right)$ and Menlo Park $\left(38^{\circ} \mathrm{N}\right)$, which are not so different except the appearance of the secondary maximum in early autumn in Fukuoka. The model proposed by Cadle et al. also can not explain the decay feature observed at two different stations, consistently. 
Taking account of the variability of the decay feature against latitude between $30^{\circ} \mathrm{N}$ and $40^{\circ} \mathrm{N}$, the 2-dimensional model proposed by Gudiksen et al. is more suitable than the one proposed by Cadle et al. in order to analyze the gross temporal variation of the post-Fuego stratospheric aerosols. Thus we adopt the model proposed by Gudiksen et al. for our purpose. It is important to note that the gross decay feature observed by lidar is not faster but slower than predicted one calculated by Gudiksen et al. It is suggested that some kinds of in situ formation process should be necessary to explain the results of lidar observation according to the 2-dimensional model proposed by Gudiksen et al. On the contrary the sedimentation has remarkable influence on the removal of the stratospheric large particles of aerosol $(r>0.3 \mu \mathrm{m})$ and if the return of the lidar emission comes mainly from these particles, the decay feature would be faster than the calculated one in the absence of any growth or formation of particles. Thus the influence of increased sedimentation will enhance the discrepancy between the observed and calculated results. The in situ formation in the lower stratosphere would occur by mean of the homogeneous or heterogeneous heteromolecular nucleation in which a solution droplet is formed from two gaseous species, water and sulfuric acid vapor. In a later paper we will discuss the case where the in situ formation in the lower stratosphere is taken into account.

Temporal variation of the height integrated $\beta_{M}$ between 15.75 and $24.75 \mathrm{~km}$ is shown in Fig. 4 , where the secondary maximum can also be seen in early autumn '75. In spring '75 the integrated $\beta_{M}$ reached about six times as great as that of pre-volcanic layer which was $0.7 \times 10^{-3}$ on average and then it gradually decreased. The mean value of the integrated $\beta_{M}$ is $2.1 \times 10^{-3}$ between Mar. '75 and Feb. '76 and $1.1 \times 10^{-3}$ between Mar. '76 and Sep. '76. Assuming the

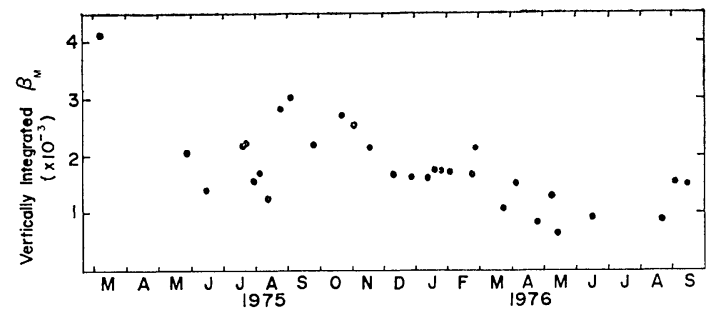

Fig. 4 Temporal variation of the height integrated $\beta_{M}$. size distribution of the aerosol particles at each height is represented by the same normalized size distribution function, the height integrated $\beta_{M}$ is proportional to aerosol optical thickness for a ruby wavelength $0.69 \mu \mathrm{m}, \tau(0.69)$, which is defined as follows,

$$
\tau(0.69)=\frac{1}{P(\pi)} \int_{15.75 \mathrm{~km}}^{24.75 \mathrm{~km}} \beta_{M}(h) d h
$$

where

$$
P(\pi)=\frac{\beta_{M}}{\beta_{\text {ext }}}
$$

is a phase function and $\beta_{\text {ext }}$ is a non-molecular extinction coefficient. Based on the Mie theory we computed the values of $\beta_{\text {ext }}$ for three different kinds of the size distribution; Power Law $n_{p}(r)$ (Junge et al., 1961), Lognormal $n_{1}(r)$ (Friend, 1966; Pinnick et al., 1976) and Deirmendjian Haze $\mathrm{H} n_{h}(r)$ (Russell et al., 1974). Their specific form are:

$$
n_{p}(r)=A_{p} r^{(\nu+1)}, \quad r \min <r<r \max
$$

where $\nu=3, r_{\min }$ and $r_{\max }$ are minimum and maximum radius respectively,

$$
n_{1}(r)=A_{1} \frac{1}{\sqrt{2} \pi s r} \exp \left[-\left\{1 n\left(r / r_{0}\right)\right\}^{2} / 2 s^{2}\right]
$$

where $r_{0}=0.35 \mu \mathrm{m}, s=0.30$ proposed by Friend and $r_{0}=0.0725 \mu \mathrm{m}, s=0.621$ proposed by Pinnick et al.,

$$
n_{h}(r)=A_{h} r^{-2} \exp (-20 r)
$$

where $A_{p}, A_{1}$ and $A_{h}$ are constants for normali-

\begin{tabular}{|c|c|c|c|}
\hline $\begin{array}{l}\text { Size } \\
\text { Distribution }\end{array}$ & $\begin{array}{l}r_{\min } . \\
(\mu \mathrm{m})\end{array}$ & $\begin{array}{l}r_{\max } . \\
(\mu \mathrm{m})\end{array}$ & $P(\pi)$ \\
\hline \multirow{6}{*}{$\begin{array}{l}\text { Junge } \\
\text { Power Law } \\
\nu^{\prime}=3\end{array}$} & 0.05 & 0.5 & 0.2344 \\
\hline & 0.08 & 0.5 & 0.2172 \\
\hline & 0.1 & 0.5 & 0.1993 \\
\hline & 0.05 & 1.0 & 0.2334 \\
\hline & 0.08 & 1.0 & 0.2212 \\
\hline & 0.1 & 1.0 & 0.2086 \\
\hline \multicolumn{3}{|c|}{ Lognormal (Friend) } & 0.1692 \\
\hline \multicolumn{3}{|c|}{ Haze $\mathrm{H}$ (Russell et al.) } & 0.1644 \\
\hline \multicolumn{3}{|c|}{ Lognormal (Pinnick et al $\mathrm{l}_{\mathrm{s}}$} & 0.1938 \\
\hline
\end{tabular}
zation. Calculated values of $P(\pi)$ for these size distributions are shown in Table 1 .

Table 1. Phase functions for various size distributions.

Usually the optical thickness for a wavelength $0.55 \mu \mathrm{m}, \tau(0.55)$, is used and the one for $0.69 \mu \mathrm{m}$, $\tau(0.69)$, is converted to $\tau(0.55)$ assuming that the non-molecular extinction varies as $\lambda^{-1}$. The 
values of $\tau(0.55)$ of the post-Fuego aerosols are between 3.2 and $0.59\left(\times 10^{-2}\right)$ for Haze $\mathrm{H}$ size distribution and between 2.3 and $0.45\left(\times 10^{-2}\right)$ for Junge power law size distribution in which the radii of aerosols are in the size range $0.08<r<1 \mu \mathrm{m}$.

\section{Concluding remarks}

The temporal variation of the post-Fuego stratospheric aerosol layer from Mar. '75 to Sep. '76 observed by lidar in Fukuoka is described and is compared with the 2-dimensional transport models proposed by Gudiksen et al. and Cadle et al. In this paper, we confine our attention to the case in which the production of the particles in the embryonic size range is neglected and so the observed value $\beta_{M}$ is well conservative. The decay of the observed values is much slower than the one expected from the result calculated by Gudiksen et al. Another model proposed by Cadle et al. also can not explain consistently the decay features observed at two different stations, Fukuoka and Menlo Park, which show nearly parallel decrements at these stations. Consequently, none of the two 2-dimensional models can explain the results of lidar observations in the case of no in situ formation process in the stratosphere. If the model by Gudiksen $e t$ al. is adopted at least to give appropriate rate of decay in low latitudes, some kinds of in situ formation process should be considered to explain the observed results.

The temporal variation observed in Fukuoka shows a secondary maximum in early autumn '75, which has not been discernible at other stations.

The variation of integrated $\beta_{M}$ from $15.75 \mathrm{~km}$ to $24.75 \mathrm{~km}$ is also described in order to show the optical thickness for several size distributions.

\section{References}

Cadle, R. D., Kiang, C. S., and J. F. Louis, 1976: The global-scale dispersion of the eruption clouds from major volcanic eruptions. J. Geophys. Res., 81, 3125-3132.

Deirmendjian, D., 1969: Electromagnetic scattering on spherical polydispersions. American Elsevier.

Dyer, A. J., and B. B. Hicks, 1968: Global spread of volcanic dust from the Bali eruption of 1963. Quart. J. Royal Meteor. Soc., 94, 545-554.

Fegley, R.W., and H.T. Ellis, 1975: Lidar observations of a stratospheric dust cloud layer in the tropics. Geophs. Res. Lett., 2, 139.

Ferry, G. V., and H. Y. Lem, 1975: Changes in stratospheric aerosols collected after the eruption of volcan de Fuego. EOS Trans. Amer. Geophys. Union, 56, 366.

Friedlander, S. K., 1960: Similarity considerations for the particle size spectrum of a coagulating, sedimenting aerosol. J. Meteorol., 17, 479-483.

Friend, J.P., 1966: Properties of the stratospheric aerosol. Tellus, 18, 465-473.

Fujiwara, M., Itabe, T., and M. Hirono, 1975: Sudden increase of stratospheric aerosol content after the eruption of Fuego volcano; lidar observations in Fukuoka. Rep. Ionos. Space Res. Japan, 29, 74-78.

Gudiksen, P. H., Fairhall, A. W., and R. J. Reed, 1968: Roles of mean meridional circulation and eddy diffusion in the transport of trace substances in the lower stratosphere. J. Geophys. Res., 73, $4461-4473$.

Hirono, M., Fujiwara, M., Uchino, O., and T. Itabe, 1974: Observations of stratospheric aerosol layer by optical radar. Can. J. Chem., 52, 1560-1568.

Hirono, M., Fujiwara, M., and T. Itabe, 1976: Behavior of the stratospheric aerosols inferred from laser radar and small ion radiosonde observations. J. Geophys. Res., 81, 1593-1600.

Hirono, M., Fujiwara, M., Itabe, T., and C. Nagasawa, 1977: On the long term variation of stratospheric aerosol content after the eruption of Fuego volcano observed by Lidar. (in preparation)

Hofmann, D. J., and J. M. Rosen, 1975: Balloon cbservation of the time development of the stratospheric aerosol event of 1974-75. EOS Trans. Amer. Geophys. Union, 56, 995.

Junge, C. E., Chagnon, C. W., and J.E. Manson, 1961: Stratospheric aerosols. J. Meteorol., 18, 81-108.

Louis, J.-F., 1974: A two dimensional model of the atmosphere. Ph.D. Thesis, University of Colorado.

Pinnick, R. G., Rosen, J. M., and D. J. Hofmann, 1976: Stratospheric aerosol measurements III: optical model calculations. J. Atmos. Sci., 33, 304-314.

Russell, P. B., Viezee, W., and R.D. Hake, Jr., 1974: Lidar measurements of the stratospheric aerosol over Menlo Park, California; October 1972-March 1974. Final Report 2217, Stanford Research Institute. measurements of the stratospheric aerosol. Third Quarterly Report 4019, Stanford Research Institute.

Toon, O. B., and J. B. Pollack, 1973: Physical properties of the stratospheric aerosols. J. Geophys. Res., 78, 7051-7056.

Volz, F. E., 1975: Volcanic twilights from the Fuego eruption. Science, 189, 48-50. 


\section{ライダーによって観測された福岡に於けるフェゴ噴火後の 成層圈エアロゾル層の時間的変動}

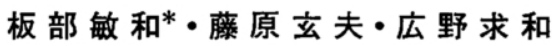

九州大学理学部物理学教室

1974 年十月中旬にガテマ.ラのフェゴ火山噴火は下部成層圈に大量の火山物質を投入した。約 1 ケ月後ライダーに よって福岡上空の下部成層圈に異常に強い散乱層が 観測された。大気分子以外のレーダー断面積のピーク值は 1974 年 12 月に最大值を示した。1975 年春以後は徐々に減少して行ったが，その年の秋に第 2 の極大值に達した。層のピ 一クの高度は通常のユンゲ層の $2 \sim 3 \mathrm{~km}$ 下にあり, 層の半値幅は最初の $2 \sim 3 \mathrm{~km}$ からピーク高度の下降と共に増大 した。

ライダーによって観測されたピーク值の時間的変動の全体的な形は今日までに提唱された 2 次元輸送モデルから期 待される結果と矛盾しているが，この矛盾は観測されたレーダー断面積が良い保存量であると仮定する限り説明でき ない。そこで下部成層圈に於て何らかの形でその場に於ける粒子生成が起っていることが示唆される。 